\title{
Impact of fishing with Tephrosia candida (Fabaceae) on diversity and abundance of fish in the streams at the boundary of Sinharaja Man and Biosphere Forest Reserve, Sri Lanka
}

\author{
Udaya Priyantha Kankanamge Epa \& Chamari Ruvandika Waniga Chinthamanie Mohotti \\ Department of Zoology \& Environmental Management, Faculty of Science, University of Kelaniya, Kelaniya 11600, \\ Sri Lanka; epa@kln.ac.lk, chamarimohotti@gmail.com
}

\author{
Received 07-V-2015. Corrected 04-III-2016. Accepted 31-III-2016.
}

\begin{abstract}
Local communities in some Asian, African and American countries, use plant toxins in fish poisoning for fishing activities; however, the effects of this practice on the particular wild fish assemblages is unknown. This study was conducted with the aim to investigate the effects of fish poisoning using Tephrosia candida, on freshwater fish diversity and abundance in streams at the boundary of the World Natural Heritage site, Sinharaja Forest Reserve, Sri Lanka. A total of seven field trips were undertaken on a bimonthly basis, from May 2013 to June 2014. We surveyed five streams with similar environmental and climatological conditions at the boundary of Sinharaja forest. We selected three streams with active fish poisoning practices as treatments, and two streams with no fish poisoning as controls. Physico-chemical parameters and flow rate of water in selected streams were also measured at bimonthly intervals. Fish were sampled by electrofishing and nets in three randomly selected confined locations ( $6 \times 2 \mathrm{~m}$ stretch) along every stream. Fish species were identified, their abundances were recorded, and Shannon-Weiner diversity index was calculated for each stream. Streams were clustered based on the Bray-Curtis similarity matrix for fish composition and abundance. Physico-chemical parameters of water were not significantly different among streams $(\mathrm{P}>0.05)$. A total of 15 fish species belonging to four different orders Cypriniformes, Cyprinodontiformes, Perciformes and Siluriformes were collected; nine species (60\%) were endemic, and six (40\%) were native species. From these, 13 fish species were recorded in streams with no poisoning, while five species were recorded in streams where poisoning was practiced. Four endemic and one native fish species were locally extinct in streams where fish poisoning was active. Fish abundance was significantly higher in control streams $\left(32-39 / \mathrm{m}^{2}\right)$ when compared to treatment streams $\left(5-9 / \mathrm{m}^{2}\right)(\mathrm{P}<0.05)$. We concluded that fish poisoning with $T$. candida may have resulted in a significant reduction in species richness, total abundance and Shannon-Weiner diversity index of fish species in the studied streams at the boundary of Sinharaja forest. We recommend that this fishing practice should be strictly regulated, and to inform local communities about the legal status of fish poisoning, its consequences and the importance of fish diversity for local livelihoods and conservation purposes. Rev. Biol. Trop. 64 (3): 1129-1141. Epub 2016 September 01.
\end{abstract}

Key words: exotic plant, Tephrosia candida, fish poisoning, Sinharaja forest.

Sri Lanka, a tropical island, boasts of the highest biodiversity per unit area of land for flowering plants and for all vertebrate groups except birds in Asia (Mahindapala, 2002). However, freshwater fish species richness of the country is in lower range with 91 indigenous, 50 endemic and 25 introduced species. The wet zone, which includes the Southwestern lowlands and the central highlands, provides habitats for most of the fresh water fish species (Senanayake \& Moyle, 1982; Pethiyagoda, 2006). Nine new fish species have been discovered from stream and riverine habitats in this area during the period of 1998-2007 (Gunawardena et al., 2007). Two-thirds of the endemic fish species of the country were recorded from 
rivers and streams, and they account for more than $90 \%$ of threatened or vulnerable fish species (Wijeyaratne, 1993).

Major streams draining into Kalu Ganga and Gin Ganga rivers, originate from Sinharaja rain forest (Jayasuriya \& Abayawardana, 2008). This has been designated by UNESCO as a Biosphere Reserve in 1978, and as a World Natural Heritage Site in 1988. Inhabitants of the 30 villages at the boundary of Sinharaja forest (Wijesooriya \& Gunathilleke, 2003) receive a part of their daily protein requirement from freshwater fish, harvested from streams and rivers, as observed in Chalakudy River, Western Ghats, India (Raghavan, Prasad, Anvar Ali, $\&$ Pereira, 2008). Cast net and pole and line are the major fishing gears used by artisanal fishers living in villages. Use of plant toxins to catch freshwater fish is illegal in Sri Lanka, but low income groups in local communities still practice this fishing method, as they are unable to buy fish or fishing gears.

T. candida (Candolle, 1825) is an erect herb, shrub or small tree, up to $3.5 \mathrm{~m}$ tall, with straggling branches from the base (Hacker, 1990). The plants in this genus are widely distributed in tropical, sub-tropical and arid regions of the world. T. candida was locally introduced in 1970s as live legume mulch, for weed control in tea plantations (Wijewardene, 1984). Local communities accidentally discovered the ichthyotoxic effects of its smashed plant parts, and fishing using this plant is now widespread in areas where the plant is readily available, as it has paved a new way of easy fishing in streams at the boundary of Sinharaja forest. Villagers use plant poisons as it is an easy method to harvest fish from streams, a practice that has also been observed in other areas such as Guyana (Archer, 1934; Martyn \& Follett-Smith, 1936; Forte, 1996; Andel, 2000), Papua and New Guinea (Barrau, 1955), Samoa (Cox, 1979), South and North America (Acevedo-Rodríguez, 1990; Kurup, Radhakrishnan, \& Manojkumar, 2004; Bijukumar, Philip, Ali, Sushama, \& Raghavan, 2013) and some African (Neuwinger, 2004) countries like Nigeria (Akpa, Ajima, Audu, \& Labte, 2010).
Tephrosia is well-known as a source of flavonoids, rotenoids, terpenoids, and sterols among their secondary metabolites (Dagne, Yenesew, \& Waterman, 1989; Andrei et al., 2002; Olatayo, 2005; Touqeer, Muhammad, \& Muhammad, 2013). Some of the ingredients isolated from $T$. candida are amorphispironone, tephrospirolactone, tephrospiroketone, deguelin, candidol (Dutt \& Chibber, 1983), tephrosin (Morah, 1985), amorpholone (Kole, Satpathi, Chowdhury, Ghosh, \& Adityachaudhury, 1992), candidone, rotenone and scillascillin (Stephen, Mckenzie, \& Wayne, 2003; Dagne et al., 1989). Tephrosin $\left(\mathrm{C}_{23} \mathrm{H}_{22} 0_{7}\right)$ is closely related to the commercial insecticide rotenone $\left(\mathrm{C}_{23} \mathrm{H}_{22} \mathrm{O}_{6}\right)$ that is widely used in killing undesirable fish (Olatayo, 2005). The active ingredients of this plant are released by mashing and grinding the plant parts and then introduced to the water environment. Though Tephrosia is used in fish poisoning by local communities in all continents of the world, the effects of this fishing practice on wild fish assemblages are currently unknown. Therefore, we evaluated the effects of fish poisoning using $T$. candida on freshwater fish diversity and abundance in streams, at the unprotected boundary of Sinharaja forest. It was hypothesized that the frequent use of $T$. candida to poison fish would significantly reduce fish diversity and abundance, leading to their local extinctions in freshwater streams.

\section{MATERIAL AND METHODS}

Sampling sites: The study was conducted at the unprotected boundary of Sinharaja forest reserve (with a total forest conservation area is $112 \mathrm{~km}^{2}$ ). Sinharaja is a lowland wet evergreen forest that is located in the Southwest area of Sri Lanka $\left(6^{\circ} 21^{\prime}-6^{\circ} 26^{\prime} \mathrm{N} \& 80^{\circ} 21^{\prime}\right.$ - $80^{\circ} 34^{\prime}$ E). It lies between the tributaries of the Kalu Ganga and the Gin Ganga rivers, and extends within the administrative districts of Galle, Matara and Ratnapura, in the Southern and Sabaragamuwa provinces, Sri Lanka (Gunatilleke, Gunatlleke, Ethugala, \& Esufali, 2004; Jayasinghe, Ekanayake, Bambaradeniya, 
\& Amarasinghe, 2005). A total of seven sampling field trips were undertaken on a bimonthly basis from May 2013 to June 2014.

A total of five streams were studied. Two streams were designated as control sites i.e. Ima ela (C1) and Katukandi ela (C2), where no $T$. candida fishing poisoning is practiced (NTF). Villagers living around these streams do not practice fish poisoning, as $T$. candida is not readily available in the area. Additionally, other three streams were selected as treatment sites ie. Hal dola (T1), Puwakgaha ela (T2) and Wadagaha hena ela (T3), and where $T$. candida fishing is frequently practiced (TF)
(Fig. 1). For this fishing practice, local villagers crush and ground around $3-5 \mathrm{~kg}$ of leaves and branches of $T$. candida with a wooden pestle and a natural rock mortar into a pulpy mass. The freshly prepared pulp is then simply thrown on the water surface in streams to poison the fish. The stunned, floating fish are then collected by hand or hand nets. They poison the streams 2-3 times a month, but fishing is not practiced on rainy days due to high flow rates in streams. T. candida is not cultivated for fishing purposes, but the plant is available in some tea plantations, abandoned agricultural lands and in some home gardens.

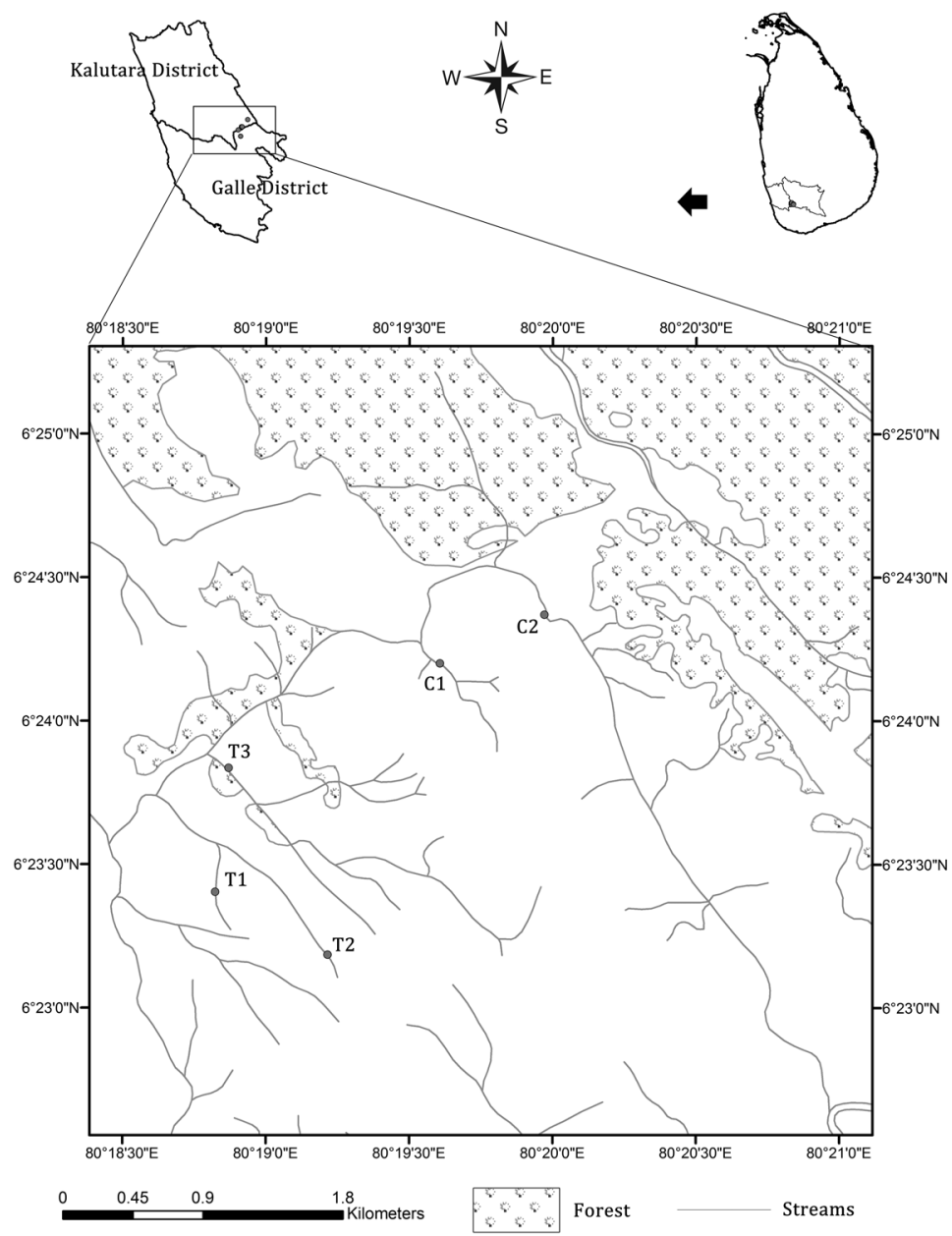

Fig. 1. Sampling streams at the unprotected boundary of Sinharaja forest

(T1, T2, T3 - subjected to fish poisoning using T. candida; C1 \& C2 - did not subject to fish poisoning). 
Water quality analysis: Water quality was monitored with a $150 \mathrm{~m}$ gap in three locations in each selected stream. Water physico-chemical parameters such as temperature (Barannan $350 \mathrm{~mm}$ glass thermometer), $\mathrm{pH}$ (HACHE 10 portable $\mathrm{pH}$ meter), total dissolved solids (TDS) (SM 401 TDS meter), dissolved oxygen (DO) and five day biochemical oxygen demand (BOD) (APHA, 2007) were measured in each visit. The water flow velocity at each sampling site was measured using the floater drifting method (Bhat, 2004). Depth of selected streams varied from 0.5-0.6 m. Water quality parameters in streams were compared by one way ANOVA followed by Tukey's pair wise comparison.

Fish sampling: Fish were sampled from three selected locations in each stream. A 150 $\mathrm{m}$ gap was maintained between adjacent sampling locations, to avoid recording of the same individuals of different fish species. Fish were encircled (6 m long stretch of $2 \mathrm{~m}$ wide stream area) with minimum disturbance by fishing nets with a mesh size of $5 \mathrm{~mm}$. Fish were captured using electro fishing gear [(Electrofisher, SAMUS 700 and collected by hand nets (mesh size $2 \mathrm{~mm}$ )] and cast nets (mesh size 5 $\mathrm{mm}$ ). Fish were identified according to Mendis and Fernando (1969); Goonathilake (2007); Silva, Maduwage and Pethiyagoda (2010); IUCN (2012); Pethiyagoda, Meegaskumbura and Maduwage (2012) and Froese and Pauly (2015). Fish were immediately released to their habitats after identification and enumeration.

Significant differences of total fish abundance and Shannon-Weiner diversity index of streams were obtained using Tukey's pairwise comparisons after two-way ANOVA. Five streams were clustered based on the BrayCurtis similarity matrix of the fish composition and abundance using PRIMER version 5.2.9 software. Statistical differences of the major clusters of fish composition and abundance in the dendrogram were obtained using one-way ANOSIM.

\section{RESULTS}

Water quality in streams: Temperature, $\mathrm{pH}$, TDS, DO and BOD in water in five selected streams varied in a narrow range and were not significantly different (One way ANOVA, Tukey's; P > 0.05) (Table 1). The water flow rate recorded in the Wadagaha hena ela (T3) stream was significantly higher than the lowest flow rate recorded in the Katukandi ela (C2) stream. Flow rates in the other streams

TABLE 1

Physico-chemical parameters of water (mean \pm sd; range in parenthesis) in NTF $(\mathrm{C} 1, \mathrm{C} 2)$ and TF $(\mathrm{T} 1, \mathrm{~T} 2, \mathrm{~T} 3)$ streams at the unprotected boundary of Sinharaja forest, Sri Lanka

\begin{tabular}{|c|c|c|c|c|c|}
\hline Physico-chemical parameter & $\mathrm{C} 1$ & $\mathrm{C} 2$ & $\mathrm{~T} 1$ & $\mathrm{~T} 2$ & $\mathrm{~T} 3$ \\
\hline \multirow[t]{2}{*}{$\mathrm{pH}$} & $6.8 \pm 0.04$ & $6.9 \pm 0.03$ & $6.9 \pm 0.02$ & $6.9 \pm 0.02$ & $6.9 \pm 0.03$ \\
\hline & $(6.6-7.1)$ & $(6.7-7.1)$ & $(6.7-7.1)$ & $(6.7-7.1)$ & $(6.7-7.1)$ \\
\hline \multirow[t]{2}{*}{ Temperature $\left({ }^{\circ} \mathrm{C}\right)$} & $26.4 \pm 0.14$ & $26.5 \pm 0.15$ & $26.5 \pm 0.14$ & $26.2 \pm 0.12$ & $26.5 \pm 0.11$ \\
\hline & $(26.8-27.3)$ & $(26.1-27.6)$ & $(26.2-27.4)$ & $(26.1-27.6)$ & $(26.3-27.5)$ \\
\hline \multirow[t]{2}{*}{ TDS (mg/L) } & $20.4 \pm 0.24$ & $20.1 \pm 0.22$ & $19.8 \pm 0.13$ & $20.5 \pm 0.21$ & $20.4 \pm 0.11$ \\
\hline & $(19.5-21.1)$ & $(19.3-21.4)$ & $(19.2-20.6)$ & $(19.8-21.2)$ & $(19.7-21.2)$ \\
\hline \multirow[t]{2}{*}{ Dissolved Oxygen (mg/L) } & $8.7 \pm 0.07$ & $8.8 \pm 0.04$ & $8.8 \pm 0.05$ & $8.9 \pm 0.04$ & $8.8 \pm 0.05$ \\
\hline & $(8.2-9.2)$ & $(8.6-9.2)$ & $(8.5-9.2)$ & $(8.6-9.2)$ & $(8.5-9.2)$ \\
\hline \multirow[t]{2}{*}{$\mathrm{BOD}_{5}(\mathrm{mg} / \mathrm{L})$} & $0.9 \pm 0.0$ & $1.0 \pm 0.0$ & $1.0 \pm 0.0$ & $1.0 \pm 0.0$ & $0.9 \pm 0.0$ \\
\hline & $(0.8-1.3)$ & $(0.8-1.4)$ & $(0.8-1.4)$ & $(0.8-1.2)$ & $(0.6-1.4)$ \\
\hline \multirow[t]{2}{*}{ Flow rate $(\mathrm{cm} / \mathrm{s})$} & $3.3 \pm 1.01^{\mathrm{ab}}$ & $2.1 \pm 1.02^{\mathrm{b}}$ & $4.2 \pm 1.04^{\mathrm{ab}}$ & $4.5 \pm 1.02^{\mathrm{ab}}$ & $5.1 \pm 1.01^{\mathrm{a}}$ \\
\hline & $(1.4-7.3)$ & $(1.4-3.3)$ & $(1.1-7.4)$ & $(1.4-10.2)$ & $(2.6-15.1)$ \\
\hline
\end{tabular}

Note: Values are mean $\pm \mathrm{SE}$, range in parenthesis. Different superscript letters in a row denote significant differences $(\mathrm{P}<$ 0.05) compared by two way ANOVA followed by Tukey's pairwise test. 
did not show a significant variation (One way ANOVA, Tukey's; P < 0.05).

Fish species diversity and abundance: A total of 15 fish species belonging to four different orders Cypriniformes, Cyprinodontiformes, Perciformes and Siluriformes were identified in the streams at the boundary of Sinharaja forest. Species richness of the streams ranged from 4-13, while the higher species richness was recorded in NTF streams and the lower in TF streams (Fig. 2).

Out of the 15 fish species recorded during the study, nine were endemic species (Table 2). $B$. signata, $P$. nigrofasciatus and $R$. dandiya were recorded in all TF and NTF streams. $A$. dayi, C. brachysoma, D. malabaricus, G. ceylonensis, G. giuris P. bimaculatus, P. titteya, P. vittatus and $S$. notostigma were only recorded in NTF streams. S. notostigma and P. bimaculatus were only found in Ima ela stream (C1), while $G$. giuris and D. malabaricus were only found in Katukambi ela stream (C2). Out of six species recorded in TF streams five were endemic to Sri Lanka.

$R$. dandia was the highest abundant fish in the streams at the boundary of Sinharaja forest (Table 3). Abundance of $R$. dandia, $P$. nigrofasciatus, P. dorsalis, P. singhala, S. pleurotaenia, and $B$. signata were significantly higher in NTF streams than TF streams (Two way ANOVA, Tukey's, $\mathrm{P}<0.05)$. The lowest abundance was recorded for D. malabaricus, $P$. bimaculatus and G. giuris followed by $G$. ceylonensis, A. dayi and C. brachysoma.

The total fish abundance in NTF streams was significantly higher than that of the TF streams (Table 4). The total fish abundance was very low in the Puwakgaha ela stream (T3) followed by Hal dola (T1) and Wadagahahena ela (T3) streams. The Shannon-Weiner diversity indices of the NTF streams were also higher than that of the TF streams. The ShannonWeiner diversity index was significantly lower (Two way ANOVA, Tukey's; $\mathrm{P}<0.05$ ) in the Puwakgaha ela stream (T3) compared to NTF streams (Table 4).

According to the cluster analysis, based on the Bray-Curtis similarity matrix of the fish composition and abundance, mainly two clusters were formed (Fig. 3). These two clusters that represent TF and NTF streams were significantly different from each other (one way ANOSIM; P < 0.05). Absence of A. dayi, $C$. brachysoma, D. malabaricus, G. ceylonensis, G. giuris, $P$. bimaculatus, $P$. titteya, $P$. vittatus and $S$. notostigma in TF streams and higher abundance of $R$. dandia, $P$. nigrofasciatus, $P$. dorsalis, P. singhala, S. pleurotaenia, and $B$. signata in NTF streams separated TF and NTF streams into two clusters. Meanwhile, Cluster 1 was divided into two clusters ( $1 \mathrm{a} \& 1 \mathrm{~b})$, since

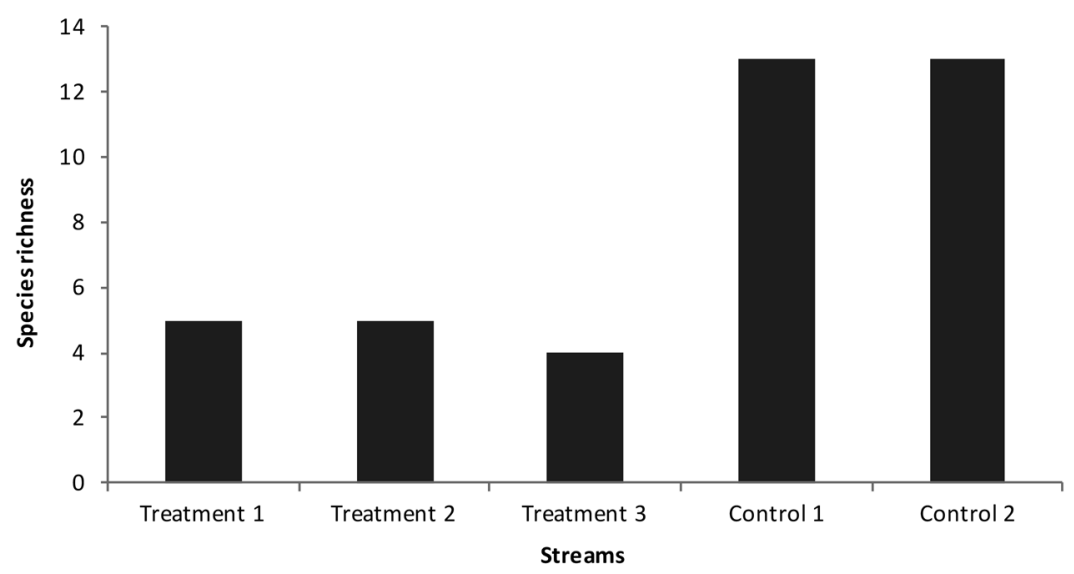

Fig. 2. Fish species richness (mean $\pm \mathrm{SD}$ ) in streams at the unprotected boundary of Sinharaja forest (Treatment 1,2 \& 3 subjected to fish poisoning using T. candida; Control $1 \& 2$ - did not subject to fish poisoning). 
TABLE 2

Fish species recorded from NTF $(\mathrm{C} 1 \& \mathrm{C} 2)$ and $\mathrm{TF}(\mathrm{T} 1, \mathrm{~T} 2 \& \mathrm{~T} 3)$ streams at the unprotected boundary of Sinharaja forest, Sri Lanka

\begin{tabular}{|c|c|c|c|c|c|c|c|}
\hline Species name & Common name & Status & $\mathrm{C} 1$ & $\mathrm{C} 2$ & $\mathrm{~T} 1$ & $\mathrm{~T} 2$ & T3 \\
\hline Aplocheilus dayi (Steindachner, 1892) & Sri Lanka day's killifish & Endemic & $\ddot{O}$ & $\ddot{O}$ & $\mathrm{x}$ & $\mathrm{x}$ & $\mathrm{x}$ \\
\hline Belontia signata (Gunther, 1861) & Sri Lanka combtail & Endemic & Ö & Ö & Ö & Ö & Ö \\
\hline Clarias brachysoma (Gunther, 1864) & Sri Lanka walking catfish & Endemic & Ö & Ö & $\mathrm{x}$ & $\mathrm{x}$ & $\mathrm{x}$ \\
\hline Devario malabaricus (Jerdon, 1849) & Giant danio & Native & $\mathrm{x}$ & Ö & $\mathrm{x}$ & $\mathrm{x}$ & $\mathrm{x}$ \\
\hline Dawkinsia singhala (Dunker, 1912) & Filamented barb & Endemic & Ö & Ö & Ö & Ö & $\mathrm{x}$ \\
\hline Garra ceylonensis (Bleeker, 1863) & Sri Lanka stone sucker & Endemic & Ö & Ö & $\mathrm{x}$ & $\mathrm{x}$ & $\mathrm{x}$ \\
\hline Glossogibius giuris (Hamilton, 1822) & Bar-eyed goby & Native & $\mathrm{x}$ & Ö & $\mathrm{x}$ & $\mathrm{x}$ & $\mathrm{x}$ \\
\hline Puntius bimaculatus (Bleeker, 1863) & Redside barb & Native & Ö & $\mathrm{x}$ & $\mathrm{x}$ & $\mathrm{x}$ & $\mathrm{x}$ \\
\hline Puntius dorsalis (Jerdon, 1849) & Long-snouted barb & Native & Ö & Ö & Ö & Ö & $\mathrm{x}$ \\
\hline Puntius titteya (Deraniyagala, 1929) & Sri Lanka cherry barb & Endemic & Ö & Ö & $\mathrm{x}$ & $\mathrm{x}$ & $\mathrm{x}$ \\
\hline Puntius vittatus (Day,1865) & Silver barb & Native & Ö & Ö & $\mathrm{x}$ & $\mathrm{x}$ & $\mathrm{x}$ \\
\hline Pethiya nigrofasciatus [Gunther, 1868] & Sri Lanka black ruby barb & Endemic & Ö & Ö & Ö & Ö & Ö \\
\hline Rasbora dandiya [Valenciennes, 1844] & Broad line strip rasbora & Native & Ö & Ö & Ö & Ö & Ö \\
\hline Schistura notostigma (Bleeker, 1863) & Sri Lanka banded mountain loach & Endemic & $\ddot{O}$ & $\mathrm{x}$ & $\mathrm{x}$ & $\mathrm{x}$ & $\mathrm{x}$ \\
\hline Systomus pleurotaenia (Bleeker,1863) & Sri Lanka black-lined barb & Endemic & Ö & Ö & $\mathrm{x}$ & $\mathrm{x}$ & Ö \\
\hline
\end{tabular}

Ö - species present, $\mathrm{x}$ - species absent.

TABLE 3

Fish abundance (mean $\pm \mathrm{sd} / \mathrm{m}^{2}$; conservation status in parenthesis) in NTF and TF streams at the boundary of Sinharaja forest, Sri Lanka

\begin{tabular}{|c|c|c|c|c|c|c|c|}
\hline Order & Family & Species & Control 1 & Control 2 & Treatment 1 & Treatment 2 & Treatment 3 \\
\hline \multirow[t]{11}{*}{ Cypriniformes } & \multirow[t]{10}{*}{ Cyprinidae } & R. dandiya (LC) & $11 \pm 1.33$ & $12 \pm 0.46$ & $2 \pm 1.92$ & $4 \pm 0.98$ & $2 \pm 0.11$ \\
\hline & & P. nigrofasciatus $(\mathrm{EN})$ & $2 \pm 0.35$ & $4 \pm 2.35$ & $1 \pm 0.93$ & $1 \pm 0.18$ & \multirow[t]{3}{*}{$1 \pm 0.30$} \\
\hline & & P. dorsalis (LC) & $2 \pm 0.35$ & $5 \pm 4.47$ & $1 \pm 0.39$ & $2 \pm 0.47$ & \\
\hline & & D. singhala (LC) & $2 \pm 1.04$ & $5 \pm 0.88$ & $2 \pm 0.29$ & $1 \pm 0.27$ & \\
\hline & & S. pleurotaenia $(\mathrm{EN})$ & $2 \pm 0.21$ & $3 \pm 1.7$ & & & \multirow[t]{7}{*}{$1 \pm 0.12$} \\
\hline & & P. vittatus (LC) & $2 \pm 0.12$ & $1 \pm 0.23$ & & & \\
\hline & & P. titteya $(\mathrm{EN})$ & $2 \pm 0.55$ & $1 \pm 0.09$ & & & \\
\hline & & G. ceylonensis (VU) & $1 \pm 0.02$ & $1 \pm 0.18$ & & & \\
\hline & & D. malabaricus (LC) & & $1 \pm 1.41$ & & & \\
\hline & & P. bimaculatus (LC) & $1 \pm 0.16$ & & & & \\
\hline & Balitoridae & S. notostigma $(\mathrm{NT})$ & $3 \pm 1.20$ & & & & \\
\hline \multirow[t]{2}{*}{ Perciformes } & Osphronemidae & B. signata $(\mathrm{NT})$ & $2 \pm 1.04$ & $3 \pm 0.44$ & $1 \pm 0.26$ & $1 \pm 0.18$ & \multirow[t]{3}{*}{$1 \pm 0.20$} \\
\hline & Gobiidae & G. giuris (LC) & & $1 \pm 0.10$ & & & \\
\hline Cyprinodontiformes & Aplocheilidae & A. dayi $(\mathrm{EN})$ & $1 \pm 0.09$ & $1 \pm 0.15$ & & & \\
\hline Siluriformes & Claridae & C. brachysoma $(\mathrm{NT})$ & $1 \pm 0.47$ & $1 \pm 0.0$ & & & \\
\hline
\end{tabular}

Conservation status of fish species are given in the parenthesis. EN - endangered, LC - least concern, NT - near threatened, VU - vulnerable (IUCN, 2012; MOE, 2012). 
TABLE 4

Abundance of fish (mean $\pm \mathrm{SD}$ ) and Shannon-Weiner diversity index (mean $\pm \mathrm{SD})$ in streams at the boundary of Sinharaja forest

\begin{tabular}{|c|c|c|}
\hline Stream & Fish abundance $\left(/ \mathrm{m}^{2}\right)$ & Shannon-Weiner diversity index \\
\hline Treatment 1 & $7 \pm 0.5^{\mathrm{a}}$ & $1.52 \pm 0.0^{\mathrm{ab}}$ \\
\hline Treatment 2 & $9 \pm 0.5^{\mathrm{a}}$ & $1.26 \pm 0.0^{\mathrm{ab}}$ \\
\hline Treatment 3 & $4 \pm 1.0^{\mathrm{a}}$ & $0.99 \pm 0.3^{\mathrm{b}}$ \\
\hline Control 1 & $32 \pm 0.0^{\mathrm{b}}$ & $2.04 \pm 0.0^{\mathrm{a}}$ \\
\hline Control 2 & $39 \pm 5.5^{b}$ & $1.98 \pm 0.1^{\mathrm{a}}$ \\
\hline
\end{tabular}

Values are mean \pm SE. Different superscript letters in a column denote significant differences (Two way ANOVA, Tukey's, $\mathrm{P}<0.05)$.

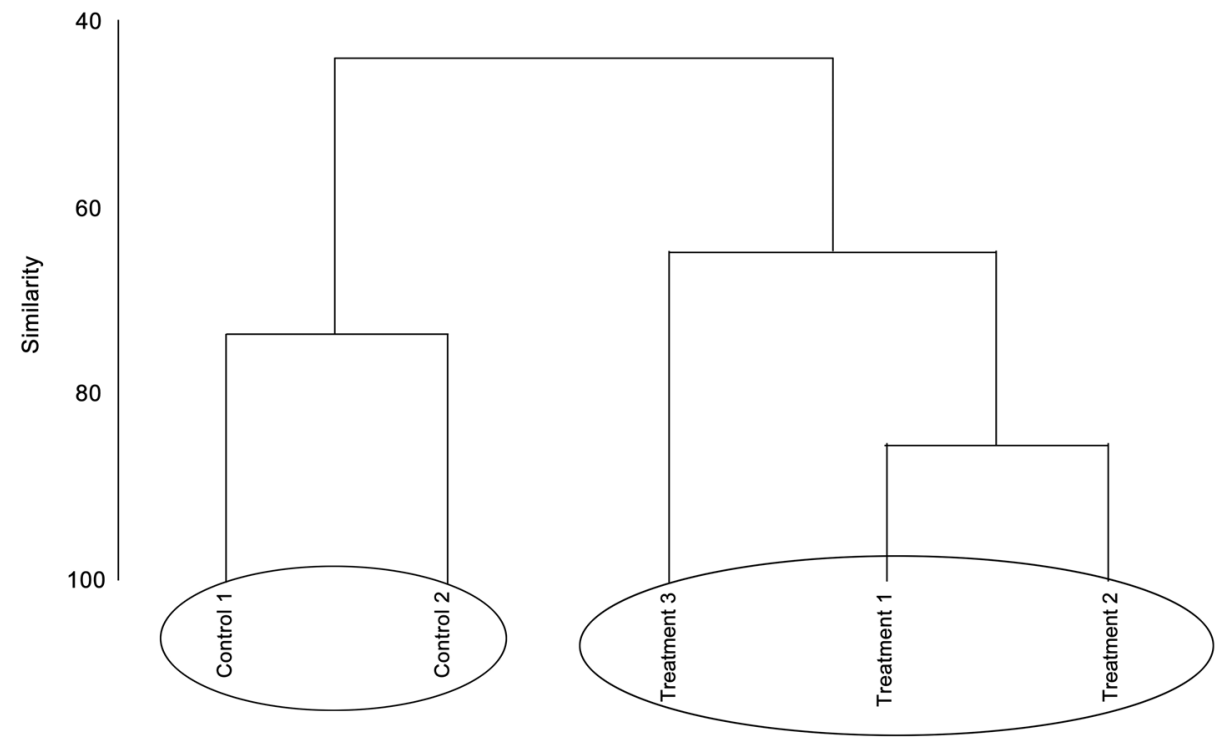

Fig. 3. Dendrogram of streams resulting from a hierarchical cluster analysis of fish abundance and composition data. (Treatment 1, $2 \& 3$ - streams subjected to fish poisoning using T. candida; Control $1 \& 2$ - streams that did not subject to fish poisoning).

there were two species only for the cluster of control stream 1, but not for control stream 2; besides, other two species were only distributed in the cluster of control 2 but not in control 1cluster. Six species were only present in cluster II, four species in cluster of treatment 3 (2a), and five species in cluster for both treatments 1 and 2 (2b). Use of $T$. candida to poison fish by local communities has changed fish diversity and abundance in streams at the boundary of Sinharaja forest.

\section{DISCUSSION}

Variation of physico-chemical parameters of water in streams in a narrow range without significant differences may be due to similar geographical and climatic conditions shared by all the treatment and control streams. Among the 15 species that inhabit the streams, nine species $(60 \%)$ were endemic, and six (40\%) were native species (IUCN, 2012; MOE, 2012). Galle and Matara districts, that share larger part 
of Sinharaja forest, harbor 64 and 57 freshwater fish species, respectively (De Silva et al., 2009). Stream and riverine habitats of unprotected boundary of Western Ghats, India, provide habitats for 32 fish species (Abraham \& Kelkar, 2012). The comparatively lower fish diversity observed in the present study may be attributed to the low habitat heterogeneity of the sampling area. However, the conservational importance of stream habitats at the unprotected boundary of Sinharaja forest is highlighted by recording four endangered, one vulnerable and three near threatened endemic fish species in the respective streams. This is in agreement with Goonatilake (2012), who indicated that the majority of threatened and endemic freshwater species, inhabit in streams that are lying outside the protected area of the country.

According to differences in diversity and abundance of fish in TF and NTF streams, they were classified into two clusters through Bay Curtis similarity matrix. The presence of $B$. signata, D. singhala, $P$. dorsalis, $P$. nigrofasciatus and $R$. dandiya in all the streams, except in Wadagaha hena ela stream (T3) (where $D$. singhala, $P$. dorsalis were absent), exhibits the ability of these fish species to resist fishing induced local extinctions and/or their ability to recolonize within a short period of time. Here, local extinction refers to the loss of the entire population of particular fish species from all the sampling locations in a stream. Lower number of individuals of these species recorded in streams subjected to fish poisoning compared to their numbers in NTF streams suggests their inability to further resist the pressure imposed by plant toxins. ShannonWeiner diversity index was also lower in the TF sites than the NTF sites. The lowest value for Shannon-Weiner diversity index was recorded for TF stream three $(0.99 \pm 0.3)$, while the highest value $(2.04 \pm 0.0)$ was recorded for the NTF stream one. If this fishing practice continues into other streams, these fish species may face a threat of local extinction as there is less chance of recovery and recolonization in freshwater ecosystems compared to other aquatic ecosystems (Pullin, 1990).
Though B. signata and P. nigrofasciatus were recorded in all the streams in the present study, their population sizes have noticeably reduced in other areas of the country, mainly because of over exploitation for aquarium trade (Goonathilake, 2012). However, the abundance of $B$. signata was very low in TF streams and it may face high risk of elimination/disappearance from these streams in future. This situation may be further aggravated by their solitary and territorial behavioral traits that make them poor colonizers. Colonization abilities of fish species mainly regulate local recurrence of regional species (Angermeier \& Winston, 1998). Also, S. pleurotaenia was recorded in only one TF stream while it was recorded in higher numbers in both NTF streams. This species may be highly vulnerable to fish poisoning, as it inhabits in the middle of the water column and form small schools. Some of the traits of individual fish species make them more vulnerable to environmental perturbations, and these traits increase the probability of their local extinctions (Angermeier, 1995; Bergerot, Hugueny, \& Belliard, 2015).

The response of fish assemblages to frequent poisoning was the extinction of five fish species including, A. dayi, C. brachysoma, $G$. ceylonensis, $P$. vittatus and $P$. titteya from $\mathrm{TF}$ streams. This highlights the suitability of fish assemblages as sensitive and reliable indicators of aquatic ecosystems health (Ibarra, Gevrey, Park, Lim, \& Lek, 2003; Rashleigh, 2004). These extinctions deserve priority in conservation activities because they are the first steps towards extinctions at larger spatial scales (Pitcher, 2001; Dulvy, Sadovy, \& Reynolds, 2003). Out of five species extinct from TF streams only two species, C. brachysoma and $G$. ceylonensis are considered as food fishes in Sri Lanka. The extinction of other smaller fish species (A. dayi, P. vittatus and P. titteya) from TF streams, showed the negative impact of fish poisoning on non-target species. Fish poisoning plants are even toxic to non-target aquatic macro invertebrates, Baetidae (Mayflies) and Hydropsychidae (Caddisflies) (Karunamoorthi, Bishaw, \& Mulat, 2009). A. dayi, P. vittatus 
and P. titteya are small fish, and small-bodied freshwater fish species are more vulnerable to extinction, due to their naturally small ranges (Gaston, 1994), which may put them in a more precarious position when their habitats are impacted by humans (Reynolds, Webb, \& Lorraine 2005). Decline of endemic fish species populations in the wild have been already observed in some other areas of the country due to habitat alteration, invasive species, ornamental fish trade, food fishery, heavy use of agrochemicals, gem mining and large and small scale hydropower projects (Wijeyaratne, 1993; Pethiyagoda, 1994; Pethiyagoda, 2006; Goonatilake, 2007; Goonatilake, 2012). Fish poisoning by $T$. candida has further intensified the threats faced by endemic fish species in the country, and currently, the endemic freshwater fish of Sri Lanka are classified in a highly vulnerable state (Goonatilake, 2012).

D. malabaricus, G. giuris, P. bimaculatus and $S$. notostigma were only recorded in one stream out of five streams studied. With the exception of $S$. notostigma, that is endemic and considered as vulnerable, the other three species were considered as least concern according to IUCN threatened species classification (IUCN, 2012; MOE, 2012). Significantly lower distribution and abundance of these species in streams at the boundary of Sinharaja forest may be due to their need for special habitat requirements. There is a greater risk of local extinction of these species mainly because of their rarity. D. malabaricus, G. giuris and $P$. bimaculatus are ubiquitous in other areas of the country, and its lower abundance in the streams at the boundary of Sinharaja forest, need to be further studied. D. malabaricus was highly abundant from upstream to downstream in Chalakudy River, Western Ghats, India (Raghavan et al., 2008).

Periodical killing of fish without any size disparity and indiscriminate removal may have led to permanent changes in fish diversity and abundance in streams at the boundary of Sinharaja forest. Fish poisoning in streams causes incalculable loss of juveniles and small fishes other than the target species (Ekanem,
Meinelt, Kloas, \& Knopf 2004; Akinbulumo, Fagbenro, \& Fasakin, 2005). Poison may easily flow downstream over a long distance exposing fry and fingerlings for lethal and sublethal concentrations. Ekanem et al. (2004) and Akpa et al. (2010) suggested discouraging the use of $T$. vogelii as a fish poison due to its high toxicity to fish larvae in freshwaters. When fish species eliminated completely from their native habitats there is a lower chance for quick re-colonization (Pethiyagoda, 1991). A similar fish population reduction caused by indiscriminate poisoning of streams and ponds was observed around Amerindian settlements in Guyana (Forte, 1996). Fishing-induced extinctions (Dulvy et al., 2003; Darwell et al., 2008; Chong, Lee, \& Lau, 2010) as observed in the present study, endanger biodiversity and affect ecosystem functioning. Such extinctions are probably going unnoticed, because of high levels of illegal fishing, geographic heterogeneity, and data scarcity (Castello, Arantes, Mcgrath, Stewart, \& De Sousa 2014).

Freshwater fish are highly vulnerable to human induced extinctions than their marine and terrestrial counterparts (Riccardi \& Rasmussen, 1999; Dudgeon et al., 2006; Strayer \& Dudgeon, 2010; Vaughn, 2010). However, the scientific community attention on the overexploitation of freshwater ecosystems is weaker than the attention on terrestrial (Myers, Mittermeier, Mittermeier, Dafonseca, \& Kent, 2000; Revenga \& Kura, 2003; Linke, Turak, \& Nel, 2011) and marine ecosystems, although the loss consequences could be similar if not worse (Allan et al., 2005). Illegal and unauthorized fishing practices are responsible for the collapse of fish stocks and destruction or alteration of important freshwater habitats all over the world (Mota, Sousa, Araujo, Braga, \& Antunes, 2014). Scientific information on these fishing practices is required in future planning and for the implementation of appropriate conservation and management strategies of aquatic species (Angermeier \& Winston, 1998; Dudgeon et al., 2006), especially in tropical countries, where law enforcement is comparatively weak. The findings of the present study can be used in 
policy development and planning in aquatic ecosystem conservation in Sri Lanka as well as in other countries where plant poisons are still used as a fish catching technique. The use of $T$. candida as a fishing practice should be strictly regulated, as plant poisons cause local extinctions and population reductions of fish in freshwater streams. The village communities need to be educated on the drawbacks of this fishing practice and conservational importance of freshwater fish species richness in the area.

\section{ACKNOWLEDGMENTS}

University of Kelaniya is acknowledged for the financial support to carry out the study. T. W. J. T. De Silva is acknowledged for the support in field sampling of fish. Comments from anonymous reviewers to improve the quality of the manuscript are deeply appreciated.

\section{RESUMEN}

Impacto en la diversidad y abundancia de peces en riachuelos de la frontera de la Reserva Forestal de Sinharaja, Sri Lanka al pescar con Tephrosia candida (Fabaceae). Las comunidades de algunos países asiáticos, africanos y americanos utilizan las toxinas de las plantas para pescar, sin embargo, los efectos de esta práctica en grupos de peces silvestres son desconocidos. Este estudio se llevó acabo con el objetivo de investigar los efectos del envenenamiento de peces con Tephrosia candida en la diversidad y abundancia de peces de agua dulce en riachuelos de la frontera la Reserva Sinharaja en Sri Lanka. En total se realizaron siete giras bimensuales al campo de mayo 2013 a junio 2014. Se muestrearon cinco riachuelos con condiciones ambientales y climáticas similares en la frontera de la reserva de Sinharaja. Como tratamientos se seleccionaron tres riachuelos con práctica activa de envenenamiento de peces y dos riachuelos sin envenenamiento de peces como controles. También, en intervalos bimensuales, se midieron los parámetros físico-químicos y de corriente del agua en riachuelos seleccionados. Se utilizó la electropesca y redes en tres sitios $(6 \times 2 \mathrm{~m})$ seleccionados al azar a lo largo de cada riachuelo para el muestreo de peces. Se identificaron los peces a nivel de especie, se anotó su abundancia y se calculó el índice de diversidad de Shannon-Weiner para cada riachuelo. Con base en la matriz de similitud de Bray-Curtis se agruparon los riachuelos para composición y abundancia de peces. Los parámetros físicoquímicos del agua fueron no significativamente distintos entre los riachuelos $(\mathrm{P}>0.05)$. Se recolectó un total de 15 especies de peces que pertenecen a cuatro órdenes: Cypriniformes, Cyprinodontiformes, Perciformes y Siluriformes; nueve especies (60\%) fueron endémicas y seis (40\%) nativas. Trece especies se encontraron en riachuelos donde no se practica el envenenamiento mientras que cinco especies se encontraron en riachuelos donde sí se daba esta práctica. Cuatro especies endémicas y una nativa estaban extintas en riachuelos donde la práctica del envenenamiento era activa. La abundancia de peces fue significativamente alta en los riachuelos control $\left(32-39 / \mathrm{m}^{2}\right)$ al compararse con los tratamientos $\left(5-9 / \mathrm{m}^{2}\right)(\mathrm{P}<0.05)$. Se concluye que el envenenamiento de peces con $T$. candida puede haber resultado en una reducción significativa de la riqueza de especies, la abundancia total y el índice de diversidad de Shannon-Weiner de las especies de peces en los riachuelos estudiados en la frontera de la reserva Sinharaja. Se recomienda que esta práctica de pesca sea estrictamente regulada y que se informe a las comunidades locales acerca del estado legal del envenenamiento de peces, sus consecuencias y de la importancia de la diversidad de peces para el sustento local y para propósitos de conservación.

Palabras clave: planta exótica, Tephrosia candida, envenenamiento de peces, Reserva Sinharaja.

\section{REFERENCES}

Abraham, R. K., \& Kelkar, N. (2012). Do terrestrial protected areas conserve freshwater fish diversity? Results from the Western Ghats of India. Oryx, 46, 544-553.

Acevedo-Rodríguez, P. (1990). The occurrence of piscicides and stupefactants in the plant kingdom. In G. T. Prance, \& M. J. Balick, (Eds.), New directions in the study of plants and people. Advances in Economic Botany (pp. 1-23). New York: New York Botanical Garden.

Allan, J. D., Abell, R., Hogan, Z. E. B., Revenga, C., Taylor, B. W., Welcomme, R. L., \& Winemiller, K. (2005). Overfishing of inland waters. BioScience, 55, 1041-1051.

Akinbulumo, M. O., Fagbenro, O. A., \& Fasakin, E. A. (2005). Acute toxicity of ethanolic extract of Derris elliptica roots to Oreochromis niloticus fingerlings, Department of fisheries, Federal university of technology, Nigeria. Retrieved from http: //ag.arizona.edu / azaqua/ista/ /ista6web/pdf/223.pdf

Akpa, L. E., Ajima, M. N. O., Audu, B. S., \& Labte, S. M. (2010). Effects of fish bean (Tephrosia vogelii) leave extract exposed to freshwater cichlid fish -Tilapia zilli. Animal Research International, 7(3), 1236-1241.

Andel, T. V. (2000). The diverse uses of fish poison plants in Northwest Guyana. Journal of Economic Botany, 54(4), 500-512. 
Andrei, C. C., Vieira, P. C., Fernande, J. B., Fatimadas, M., Silva, G. F., \& Rodrigues, E. (2002). New spirorotenoids from Tephrosia candida. Zeitschrift. Fur Naturforschung C, 57, 418-422.

Angermeier, P. L. (1995). Ecological attributes of extinction-prone species - loss of fresh-water fishes of Virginia. Conservation Biology, 9, 143-158.

Angermeier, P. L., \& Winston, M. R. (1998). Local vs. regional influences on local diversity in stream fish communities of Virginia. Ecology, 79(3), 911-92.

APHA. (2007). American Public Health Association Standard methods for examination of water and wastewater. $13^{\text {th }}$ Edition. D.C. USA: APHA Washington.

Archer, W. A. (1934). Fish poison plants of British Guiana, a preliminary list. Agricultural Journal of British Guiana, 5(3), 204-206.

Barrau, J. (1955). Fishing poisons of the South Pacific. SPC Quarterly Bulletin 7. Retrieved from http:// www.spc.int/ DigitalLibrary/ Doc/ FAME/ InfoBull/ SPB/ SPB5_3_Barrau.pdf

Bergerot, B., Hugueny, B., \& Belliard, J. (2015). Relating life-history traits, environmental constraints and local extinctions in river fish. Freshwater Biology, 60, 1279-1291.

Bhat, A. (2004). Patterns in the distribution of freshwater fishes in rivers of Central Western Ghats, India and their associations with environmental gradients. Hydrobiologia, 529, 83-97.

Bijukumar, A., Philip, S., Ali, A., Sushama, S., \& Raghavan, R. (2013). Fishes of River Bharathapuzha, Kerala, India: diversity, distribution, threats and conservation. Journal of Threatened Taxa, 5(15), 4979-4993.

Castello, L., Arantes, C. C., Mcgrath, D. G., Stewart, D. J., \& De Sousa, F. S. (2014). Understanding fishinginduced extinctions in the Amazon. Aquatic Conservation: Marine and Freshwater Ecosystems, 25 , 447-458. doi: 10.1002/aqc.2491

Chong, V. C., Lee, P. K. Y., \& Lau, C. M. (2010). Diversity, extinction risk and conservation of Malaysian fishes. Journal of Fish Biology, 76(9), 2009-2066.

Cox, P. A. (1979). Use of indigenous plants as fish poisons in Samoa. Economic Botany, 33(4), 397-399.

Dagne, E., Yenesew, A., \& Waterman, P. G. (1989). Flavonoids and isoflavonoids from Tephrosia fulvinervis and Tephrosia pentaphylla. Phytochemistry, 28, $3207-3210$

Darwall, W., Smith, K. A., Seddon, D., Gregor, M., Reid, M. C., Clausnitzer, G. V., \& Kalkman, V. (2008). Freshwater biodiversity - a hidden resource under threat. In J.-C. Vié, C. Hilton-Taylor \& S. N. Stuart (Eds.), The 2008 Review of The IUCN Red List of Threatened Species (pp. 126-232). Switzerland: IUCN, Gland.

De Silva, M., Akmeemana, S., Wewelwala, C. K. K., Darshana, S., Pushpanel, V., \& Aluthwala, T. (2009). Report on The Study of the Faunal Diversity in Matara District Southern, Sri Lanka, Wildlife Conservation Society, Bio diversity Research and Education Center, Galle, Sri Lanka.

Dudgeon, D., Arthington, A. H., Gessner, M. O., Kawabata, Z. I., Knowler, D. J., Leveque, C., Naiman, R. J., Prieur-Richard, A. H., Soto, D., Stiassny, M. L. J., \& Sullivan, C. A. (2006). Freshwater biodiversity: importance, threats, and status and conservation challenges. Biological Reviews, 81, 163-182.

Dulvy, N., Sadovy, Y., \& Reynolds, J. D. (2003). Extinction vulnerability in marine populations. Fish and Fisheries, 4, 25-64.

Dutt, S. K., \& Chibber, S. S. (1983). Candidol, a flavonol from Tephrosia candida. Phytochemistry, 22, 325-326.

Ekanem, A. P., Meinelt, T., Kloas, W., \& Knopf, K. (2004). Early life stage toxicity of extracts from the African fish poison plants Tephrosia vogelii Hook. f. and Asystasia vogeliana Benth. on zebrafish embryos. Journal of Fish Biology, 65(2), 489-494.

Forte, J. (1996). Macushi lifestyle and biodiversity use. Iwokrama International Rainforest Programme and Amerindian Research Unit. Georgetown: University of Guyana.

Froese, R., \& D. Pauly (Eds.). (2015). FishBase. World Wide Web electronic publication.

Gaston, K. J. (1994). Rarity. London, UK: Chapman \& Hall.

Goonatilake, S. de A. (2007). Freshwater fishes of Sri Lanka, Ministry of Environment, Sri Lanka. Retrieved from http: //www. environmentmin. gov.lk/ web/ images /pdf/ freshwater\%20fish.pdf

Goonatilake, S. de A. (2012). The taxonomy and conservation status of the freshwater fishes in Sri Lanka. In D. K. Weerakoon, \& S. Wijesundara (Eds.), The National Red List 2012 of Sri Lanka; Conservation Status of the Fauna and Flora (pp. 77-81). Colombo, Sri Lanka: Ministry of Environment.

Gunatilleke, C. V. S., Gunatlleke, I. A. U. N., Ethugala, E. U. K., \& Esufali, S. (2004). Ecology of Sinharaja rain forest and the forest dynamics plot in Sri Lanka's natural world heritage site. Colombo, Sri Lanka: Wild Heritage Trust.

Gunawardene, N. R., Daniels, D., Gunatilleke, A. E., Gunatilleke, I. A. U. N., Karunakaran, C. V. S., Geetha Nayak, P. V., Prasad, K., Puyravaud, S., Ramesh, P., Subramanian, B. R., \& Vasanthy, G. A. (2007). Brief 
overview of the Western Ghats - Sri Lanka biodiversity hotspot. Current Science, 93(11, 10), 1567-1572.

Hacker, J. B. (1990). A guide to herbaceous and shrub legumes of Queensland. St Lucia, Queensland: University of Queensland Press.

Ibarra, A. A., Gevrey, M., Park, Y. S., Lim, P., \& Lek, S. (2003). Modelling the factors that influence fish guilds composition using a back-propagation network: assessment of metrics for indices of biotic integrity. Ecological Modelling, 160, 281-290.

IUCN. (2012). The IUCN Red List of Threatened Species. Retrived from http://www.iucnredlist.org

Jayasinghe, C. D., Ekanayake, S. P., Bambaradeniya, C. N. B., \& Amarasinghe, S. (2005). Tropical rainforests: A resource book for secondary school teachers. Sri Lanka: IUCN.

Jayasuriya, A. H. M., \& Abayawardana, S. D. (2008). A study to determine the changes in the biodiversity values of southern Sinharaja and Kanneliya forests after the implementation of GEF medium sized project. Integrated Development Association (IDEA), United Nations Development Programme (UNDP).

Karunamoorthi, K., Bishaw, D., \& Mulat, T. (2009) Toxic effects of traditional Ethiopian fish poisoning plant Milletia ferruginea (Hochst) seed extract on aquatic macroinvertebrates. European Review for Medical and Pharmacological Sciences, 13, 179-185.

Kole, R. K., Satpathi, C., Chowdhury, A., Ghosh, M. R., \& Adityachaudhury, N. (1992). Isolation of amorpholone, a potent rotenoid insecticide from Tephrosia candida. Journal of Agricultural and Food Chemistry, 40, 1208-1210.

Kurup, B. M., Radhakrishnan, K. V., \& Manojkumar, T. G. (2004). Biodiversity status of fishes inhabiting rivers of Kerala (S. India) with special reference to endemism, threats and conservation measures. In R. L. Welcome, \& T. Petr (Eds.). Proceedings of LARS2. 2nd large rivers symposium (pp. 27-41). Mekong River Commission and Food and Agricultural Organization.

Linke, S., Turak, E., \& Nel, J. (2011). Freshwater conservation planning: the case for systematic approaches. Freshwater Biology, 56, 6-20.

Mahindapala, R. (2002). Sri Lanka. J. Carew-Reid (Ed.), Biodiversity Planning in Asia (pp. 231-253). Gland, Switzerland \& Cambridge, UK: IUCN.

Martyn, E. B., \& Follett-Smith, R. R. (1936). The fish poison plants of British Guiana, with special reference to the genera Tephrosia and Lonchocarpus. Agricultural Journal of British Guiana, 7(3), 154-159.
Mendis, A. S., \& Fernando, C. H. (1962). A guide to the freshwater fauna of Ceylon. Bulletin of the Fisheries Research, 12, 1-160.

MOE (2012). The National Red List 2012 of Sri Lanka; Conservation Status of the Fauna and Flora. Colombo, Sri Lanka: Ministry of Environment (MOE).

Morah, F. N. I. (1985). Constituents of the stem of Adenia cassia. Journal of Science Education, I, 177-183.

Mota, M., Sousa, R., Araujo, J., Braga, C., \& Antunes, C. (2014). Ecology and conservation of freshwater fish: time to act for a more effective management. Ecology of Freshwater Fish, 23, 111-113.

Myers, N., Mittermeier, R., Mittermeier, G. C., Dafonseca, G. A. B., \& Kent, J. (2000). Biodiversity hotspots for conservation priorities. Nature, 403, 853-858.

Neuwinger, H. D. (2004). Plants used for poison fishing in tropical Africa. Toxicon, 44(4), 417-430.

Olatayo, V. S. (2005) Studies of the effects from extracts from two local plants (Tephrosia vogelii and Parkia clappertoniana) on Clarias gariepinus (Tengels). In 19th Annual Conference of the Fisheries Society of Nigeria (FISON), Ilorin, Nigeria. Retrieved from http://aquaticcommons.org/4002/

Pethiyagoda, R. (1991). Freshwater fishes of Sri Lanka. Sri Lanka, Colombo: The Wildlife Heritage Trust of Sri Lanka, Colombo.

Pethiyagoda, R. (1994). Threats to the indigenous freshwater fishes of Sri Lanka and remarks on their conservation. Hydrobilogia, 285, 189-201.

Pethiyagoda, R. (2006). Conservation of Sri Lankan freshwater fishes. In C. N. B. Bambaradeniya (Ed.), Fauna of Sri Lanka: Status of Taxonomy, Research and Conservation (pp. 103-112). Sri Lanka: The World Conservation Union, Colombo, Sri Lanka and Government of Sri Lanka.

Pethiyagoda, R., Meegaskumbura, M., \& Maduwage, K. (2012). A synopsis of the South Asian fishes referred to Puntius (Pisces: Cyprinidae.). Ichthyological Exploration of Freshwaters, 23(1), 69-95.

Pitcher, T. J. (2001). Fisheries managed to rebuild ecosystems? Reconstructing the past to salvage the future. Ecological Applications, 11, 601-617.

Pullin, R. S. V. (1990). Down-to-earth thoughts on conserving aquatic genetic diversity. Naga, 13(1), 5-8.

Raghavan, R., Prasad, G., Anvar Ali, P. H., \& Pereira, B. (2008). Fish fauna of Chalakudy River, part of Western Ghats biodiversity hotspot, Kerala, India: patterns of distribution, threats and conservation needs. Biodiversity Conservation, 17, 3119-3131. 
Rashleigh, B. (2004). Relation of environmental characteristics to fish assemblages in the Upper Broad River Basin, North Carolina. Environmental Monitoring and Assessment, 93, 139-156.

Revenga, C., \& Kura, Y. (2003). Status and trends of biodiversity of inland water ecosystems (CBD Technical Series 11). Montreal, Canada.

Reynolds, J. D., Webb, J. W. T., \& Lorraine, A. H. (2005) Life history and ecological correlates of extinction risk in European freshwater fishes. Canadian Journal of Fisheries Aquatic Science, 62, 854-862.

Riccardi, A., \& Rasmussen, J. B. (1999). Extinction rates of North American freshwater fauna. Conservation Biology, 13, 1220-1222.

Senanayake, F. R., \& Moyle, P. B. (1982). Conservation of freshwater fishes of Sri Lanka. Biological Conservation, 22, 181-195.

Silva, A., Maduwage, K., \& Pethiyagoda, R. (2010). A review of the genus Rasbora in Sri Lanka, with description of two new species (Teleostei: Cyprinidae). Ichthyological Exploration of Freshwaters, 21(1), 27-50.

Stephen, L. L., Mckenzie, C. L., \& Wayne, B. H. (2003). Toxicity and repellency of Tephrosia candida to larval and adult Diaprepes Root Weevil (Coleoptera:
Curculionidae), Journal of Economic Entomology, 96(3), 811-816.

Strayer, D. L., \& Dudgeon, D. (2010). Freshwater biodiversity conservation: Recent progress and future challenges. Journal North American Benthological Society, 29, 344-358.

Touqeer, S., Muhammad, A. S., \& Muhammad, A. (2013). A Review on the Phytochemistry and Pharmacology of Genus Tephrosia. Phytopharmacology, 4(3), 598-637.

Vaughn, C. C. (2010). Biodiversity Losses and ecosystem function in freshwaters: emerging conclusions and research directions. BioScience, 60(1), 25-35.

Wijesooriya, W. A. D. A., \& Gunathilleke, C. V. S. (2003). Buffer zone of the Sinharaja biosphere reserve in Sri Lanka and its management strategies. Journal of the National Science Foundation of Sri Lanka, 31(1 \& 2), 57-71

Wijewardene, R. (1984). Techniques and tools for weed management. Weeds and weedicides, Proceedings of the Sri Lanka Association for the Advancement of Science (SLAAS), Sri Lanka. 26 ${ }^{\text {th }}$ Annual Scientific Sessions, 26-30.

Wijeyaratne, M. J. S. (1993). Conservation of freshwater fish biodiversity in Sri Lanka. Conservation \& sustainable development, 1, 61-73. 
